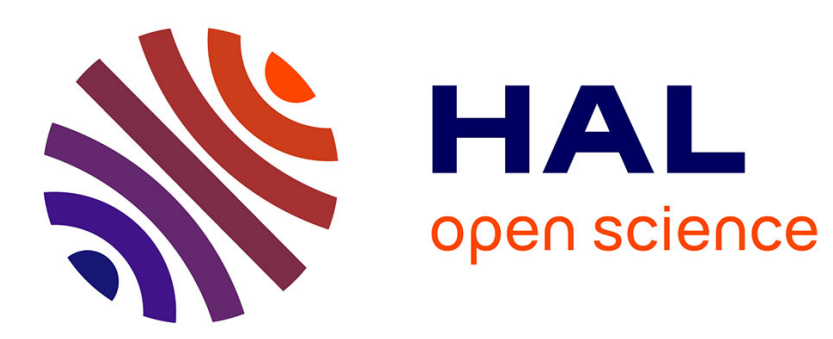

\title{
Effect of the concentration and duration of methyltestosterone treatment on masculinization rate in the brown trout (Salmo trutta)
}

B. Chevassus, Francine Krieg

\section{- To cite this version:}

B. Chevassus, Francine Krieg. Effect of the concentration and duration of methyltestosterone treatment on masculinization rate in the brown trout (Salmo trutta). Aquatic Living Resources, 1992, 5, pp.325-328. hal-02712795

\section{HAL Id: hal-02712795 \\ https://hal.inrae.fr/hal-02712795}

Submitted on 1 Jun 2020

HAL is a multi-disciplinary open access archive for the deposit and dissemination of scientific research documents, whether they are published or not. The documents may come from teaching and research institutions in France or abroad, or from public or private research centers.
L'archive ouverte pluridisciplinaire HAL, est destinée au dépôt et à la diffusion de documents scientifiques de niveau recherche, publiés ou non, émanant des établissements d'enseignement et de recherche français ou étrangers, des laboratoires publics ou privés. 
Aquat. Living Resour., 1992, 5, 325-328

Notes

\title{
Effect of the concentration and duration of methyltestosterone treatment on masculinization rate in the brown trout (Salmo trutta)
}

\author{
Bernard Chevassus and lirancine Krieg \\ INRA, Laboratoire de C'énélique des Poissons, $7 \% 352$ Jouy-en-Josar Ciedex, France. \\ Reccived July ro, 1992; arcepted October 29, 1992.
}

Chevassus B., I: Krieg. Aquat. Living. Resour., 1992, 5, 325-328.

Effet de la concentration et de la durée d'un traitement à la méthyltestostérone sur le taux de masculinisation de la truite commune (Salmo trutta).

\section{INTRODUCTION}

Oral administration of $17 \alpha$-methyltestosterone at a concentration of $3 \mathrm{mg} / \mathrm{kg}$ diet for 60 to 90 days is commonly used in salmonids to induce sex reversal, i.e. to produce neomales (genetic females inverted to phenotypic males). This treatment has been reported to produce a high proportion of sex-inverted females exhibiting a sterile filiform gonad (Johnstone et al., 1978, in the atlantic salmon Salmo salar, Johnstone et al., 1979, in the rainbow trout Oncorhynchus mykiss, Quillet et al., 1991, in the brown trout Salmo trutta).

Reducing the duration of the treatment and especially the dose level led in the rainbow trout to a considerable increase in the number of males exhibiting a functional ductus deferens (Cousin-Gerber et al., 1989). A shorter treatment was shown also to be efficient in the brown trout (table 1). The purpose of the present study was thus to apply the same protocol to the brown trout, i.e. to test two concentrations $(0.5$ and $3 \mathrm{mg} / \mathrm{kg}$ diet) and two durations (60 and 80 days) in monosex female populations.

\section{MATERIAL AND METHODS}

Experimental animals were issued from eggs produced by a group of fifteen 2-year-old females (strains SYN79) and fertilized on December 12, 1988 by 22 neomales from the same strain and obtained by gynogenesis followed by a methyltestosterone treatment (Quillet et al., 1991). Incubation was carried out in a thermoregulated tank at Jouy-en-Josas $\left(10 \pm 0.2^{\circ} \mathrm{C}\right)$. Eyed eggs were transferred to the experimental pond of Gournay-sur-Aronde where hatching took place on 18 January, 1989.

Methyltestosterone dissolved in ethanol was incorporated to a standard commercial diet (Trouvit) at a concentration of $40 \mathrm{ml} / \mathrm{kg}$ diet. The diet was fed ad libitum from the beginning of feeding (February 2, 1989) for 600 and 800 degree-days, respectively.

At sexual maturity, the phenotype (mature male, mature female, immature), the sex type of each gonad (male, female, hermaphrodite) and the total weight of the testicular zones for both gonads were determined. A group of control males from the same strain was slaughtered simultaneously and the testis weight was measured. Moreover, a group of 10 neomales issued from the same population was tested during 
Table 1. - Masculinization rate (MR: \% of total size) and functional male rate ( $F$ : $\%$ of the total number of males) in relation with the dose level and the duration of the treatment.

\begin{tabular}{|c|c|c|c|c|c|c|c|c|}
\hline \multirow{3}{*}{$\begin{array}{l}\text { Dose (mg/kg) } \\
\text { Duration (days) } \\
\text { Species }\end{array}$} & \multicolumn{4}{|c|}{3} & \multicolumn{4}{|c|}{0.5} \\
\hline & \multicolumn{2}{|c|}{60} & \multicolumn{2}{|c|}{$80-90\left(^{3}\right)$} & \multicolumn{2}{|c|}{60} & \multicolumn{2}{|c|}{90} \\
\hline & MR & F & MR & $F$ & $M R$ & $\mathrm{~F}$ & MR & $\mathrm{F}$ \\
\hline Rainbow trout $\left({ }^{1}\right)$ & 88.6 & 40.2 & 93.0 & 20.6 & 97.6 & 84.0 & 92.7 & 78.3 \\
\hline \multicolumn{9}{|l|}{ Brown trout $\left({ }^{2}\right)$} \\
\hline 1982 & - & .. & 90.1 & 1.4 & & & & \\
\hline 1983 & 30.9 & 25.7 & - & - & & & & \\
\hline 1986 & 73.1 & 29.7 & - & - & & & & \\
\hline 1987 & - & - & 74.3 & 1.1 & & & & \\
\hline
\end{tabular}

(') Cousin-Gerber et al., 1989.

(2) Quillet at al., 1991.

$\left.{ }^{3}\right) 90$ days for rainbow trout and brown trout exp. 1987; 80 days for brown trout exp. 1982, 1983 and 1987.

Table 2. - Distribution of the different sexual types observed at two and three years in relation with the dose level and the duration of the treatment.

\begin{tabular}{|c|c|c|c|c|c|c|c|c|}
\hline \multirow{2}{*}{$\begin{array}{l}\text { Dose (mg/kg) } \\
\text { Duration (days) }\end{array}$} & \multicolumn{3}{|c|}{3} & \multicolumn{4}{|c|}{0.5} & \multirow{2}{*}{ Control } \\
\hline & \multicolumn{2}{|c|}{60} & 80 & & 60 & & 80 & \\
\hline Numbers examined & 1 & & 171 & & 140 & & 81 & 127 \\
\hline \multicolumn{9}{|l|}{ Males: } \\
\hline Matures at 2 years $\left({ }^{1}\right)$ & 46.2 & $\ldots * \ldots$ & 64.5 & - ** & 13.1 & & 20.7 & - \\
\hline Matures at 3 years (') & 14.2 & & 20.2 & & 1.7 & & 7.6 & - \\
\hline Toral & 60.4 & -**- & 84.7 & - $* * *$ & 14.8 & $\ldots * \ldots$ & 28.3 & 0 \\
\hline$\%$ functionals $\left({ }^{2}\right)$ & 3.4 & & 1.7 & & 14.3 & & 7.7 & \\
\hline \multicolumn{9}{|l|}{ Females: } \\
\hline Matures at 2 years $\left({ }^{1}\right)$ & 3.3 & & 3.4 & $-^{* *}-$ & 25.5 & & 20.5 & - \\
\hline Matures at 3 years $\left({ }^{1}\right)$ & 36.3 & -** & 8.4 & —** & 59.7 & & 51.2 & - \\
\hline Steriles $\left({ }^{1}\right)$ & 0 & & 3.5 & & 0 & & 0 & - \\
\hline Total $\left({ }^{\mathrm{t}}\right)$ & 39.6 & -**- & 15.3 & $\ldots * *$ & 85.2 & - & 71.7 & 100 \\
\hline
\end{tabular}

( $\left.{ }^{1}\right) \%$ of the number in sample; $\left({ }^{2}\right) \%$ of observed males.

* Significant at $5 \% ; * *$ significant at $1 \%$.

autumn 1989 to confirm the all-female character of their untreated progeny.

\section{RESULTS}

At slaughter, the monosex control group consisted only of females. In the treated groups, a marked difference (table 2) was observed at two years of age between the groups subjected to two different concentrations: a large number of males was observed in both groups treated with $3 \mathrm{mg} / \mathrm{kg}$ diet, while the group treated with $0.5 \mathrm{mg} / \mathrm{kg}$ diet included a small number of males and a large number of ovulated females.

This result was confirmed at the age of three: most immature animals at the age of two became females in the groups treated with the low dose level, whereas the high dose level led to the production of new males. The masculinization rate ranged between 14.8 and $84.7 \%$ according to the duration of the treatment and especially the dose level.

By contrast, the number of functional (spontaneously fluent) males remained small for all the treatments, even though a slight increase was observed at the low concentration $(2.6 \%$ for $3 \mathrm{mg} / \mathrm{kg}$ diet, $12,8 \%$ for $0.5 \mathrm{mg} / \mathrm{kg}, \chi^{2}=6.1$ significant at $5 \%$ ).

At slaughter, all the animals cxhibiting a mature phenotype showed at least a partial masculinization of one of the gonads. Conversely, the animals with a female phenotype possessed totally female gonads. Few results were collected at the age of three. As they werc similar to those obtained on two-year-old fish they were pooled. Among the animals with a malc phenotype, differences between treatments were observed in the number of totally or partially masculinized gonads (table 3 ): masculinization was high with long treatments, moderate with shorter treatments. With 80-day-long treatments, more than $90 \%$ of the animals presented at least one masculinized gonad 
Table 3. - Distribution of the different types of gonads in relation with the level and the duration of the treatment in mature phenotypically male individuals $(\mathrm{M}=\mathrm{Male} ; \mathrm{F}=$ Female; $\mathrm{H}=$ Hermaphrodite).

\begin{tabular}{|c|c|c|c|c|c|c|c|c|c|}
\hline \multirow{3}{*}{$\begin{array}{l}\text { Dose }(\mathrm{mg} / \mathrm{kg}) \\
\text { Duration (days) } \\
\text { Numbers examined }\end{array}$} & \multicolumn{4}{|c|}{3} & \multicolumn{4}{|c|}{0.5} & \multirow{3}{*}{$\begin{array}{c}\text { Control } \\
29\end{array}$} \\
\hline & \multicolumn{2}{|l|}{60} & \multicolumn{2}{|l|}{80} & \multicolumn{2}{|l|}{60} & \multicolumn{2}{|l|}{80} & \\
\hline & \multicolumn{2}{|l|}{48} & \multicolumn{2}{|l|}{72} & \multicolumn{2}{|l|}{17} & \multicolumn{2}{|l|}{12} & \\
\hline \multicolumn{10}{|l|}{ Right gonad: } \\
\hline $\mathrm{M}(\%)$ & 39.6 & & 47.2 & & 17.6 & & 41.6 & & 100 \\
\hline$H(\%)$ & 25.0 & & 25.0 & & 17.6 & & 16.6 & & - \\
\hline$\Gamma(\%)$ & 35.4 & & 27.8 & & 64.8 & & 41.8 & & - \\
\hline \multicolumn{10}{|l|}{ Left gonad: } \\
\hline$M(\%)$ & 72.9 & & 91.7 & & 29.4 & & 91.7 & & 100 \\
\hline II $(\%)$ & 27.0 & & 8.3 & & 70.6 & & 8.3 & & - \\
\hline \multicolumn{10}{|l|}{ The two gonads: } \\
\hline $\mathrm{MM}$ & 39.6 & & 44.4 & & 17.6 & & 41.7 & & 100 \\
\hline MH & 16.6 & 72.8 & 25.0 & 94.4 & 5.9 & 29.4 & 8.3 & 91.7 & - \\
\hline $\mathrm{MF}$ & 16.6 & & 25.0 & & 5.9 & & 41.7 & & - \\
\hline $\mathrm{HH}$ & 8.3 & & 2.8 & & 11.8 & & 8.3 & & - \\
\hline $\mathrm{HF}$ & 18.9 & & 2.8 & & 41.2 & & 0 & & - \\
\hline $\begin{array}{l}\text { Weight of the testiculat } \\
\text { zone ( } \% \text { total body } \\
\text { weight) }\end{array}$ & $3.12^{*}$ & & 4.0 & & $2.67^{*}$ & & 3.94 & & 4.29 \\
\hline
\end{tabular}

* Significantly lower than the control $(p<5 \%)$.

versus 29.4 and $72.8 \%$ for 60 -day-long treatments. respectively with 0.5 and $3 \mathrm{mg} / \mathrm{kg} \mathrm{dict}$.

The two gonads exhibited a marked dissymmetry in their response to the treatment: the left gonad was always at least partly masculinized whcreas $55.2 \%$ of mature makes exhibited a totally fomale right gonad.

Analysing the weight of the testicular zone led to the same conclusion: it was almost equal to that of control males in the groups subjected to long treatments and significantly smaller with short treatments.

In all the animals with a male phenotype, the female zone was always composed of small-sized oocytes: no mature synchronous hermaphrodite was observed.

\section{DISCUSSION AND CONCLUSION}

These results obtained with methyltestosterone at $3 \mathrm{mg} / \mathrm{kg}$ diet are in agreement with those of Quillet et al. (1991): a large masculinization was achieved, but most of the males were not functional.

Reduction in the treatment concentration led to a marked decrease in masculinization. It had been demonstrated that a lower concentration $(0.5 \mathrm{mg} / \mathrm{kg}$ diet) was efficient in the rainbow trout (Okada et al., 1981, in Yamazaki, 1983; Cousin-Gerber et al., 1989; Van Den Hurk and Lambert, $1982-0.6 \mathrm{mg} / \mathrm{kg}$ diet). By contrast, a treatment with $0.1 \mathrm{mg} / \mathrm{kg}$ was shown to be inefficient and to our knowledge, no intermediate concentration has been tested. Thus, a more thorough investigation of the efficient concentrations should be performed in the brown trout.

Reducing the dose level and the duration of the treatment did not increase noticeably the number of functional males, contrary to the results obtained in the rainbow trout (Cousin-Gerber et al., 1989) in similar experimental conditions. However, in spite of the small size of the populations tested, a significant trend towards an increase in this parameter was observed for short treatments at a low dose level. Wider variations in these parameters should be tested in further experiments.

The marked dissymetry in the gonad response to the treatment (the right ovary being more refractory) is surprising and had not yet been mentioned in the literature. Ashby (1957 had noticed that the right ovary was smaller following alcohol incorporation in the diet. Mrsic (1923) had also noticed that the right ovary was slightly lower in the juvenile rainbow trout. Further research should be made to determine a possible dissymmetry in sex differentiation or a different sensitivity of the two gonads to circulating steroids.

\section{REFERENCES}

Ashby K, R., 1957. The effect of steroid hormones on the brown trout (Salmo trutta L.) during the period of gonadal differentiation. J. Embryol. Exp. Morphol, 5, 225 249. 
Cousin-Gerber M., G. Burger, C. Boisseau, B. Chevassus, 1989. Effect of methyltestostcrone on sex differentiation and gonad morphogenesis in rainbow trout Oncorhynchus mykiss. Aquat. Lizing Resour., 2, 225-230.

Hurk (Van Den) R., J. I). G. Lambert, 1982. Temperature and steroid effects on gonadal sex differentiation in rainbow trout. In: Symp. Reprod. Physiol. of Fish, Wageningen, 69-72.

Johnstone R., T. H. Simpson, A. F. Youngson, 1978. Sex several in Salmonid culture. Aquaculture, 13, 115-134.

Johnstone R., T. H. Simpson, A. F. Youngson, C. Whitehead, 1979. Sex reversal in Salmonid culture. Part II. The progeny of sex reversed Rainbow Trout. Aquaculture, 1i, 13-19.
Mrsic W., 1923. Die Spätbefruchtung und deren Finfluh auf Entwicklung und geschlechtbildung, experimentell nachgeprüft an der Regenbogenforelle. Arch. Mikr. Anat., So, 129-209.

Okada H., H. Matsumoto, Y. Murakami, 1981. Ratio of induced males from genetic females at various dictary concentrations of methyltestosterone. Ann. Meet. Jpn. Sec. Sci. Fish., Ahstract, p. 33 (in Japancsc).

Quillet E., L. Foisil, B. Chevassus, D. Chourrout, F. G. Liu, 1991. Production of all-triploid and all-female brown trout for aquaculture. Aquat. Lizing Resour., 4, 27-32.

Yamaraki I:., 1983. Sex control and manipulation in fish. Aquaculture, 33, 329-354. 